\title{
Cloning and endogenous expression of a Eucalyptus grandis UDP-glucose dehydrogenase cDNA
}

Mônica T. Veneziano Labate, Ana L. Ferreira Bertolo, Daniela Defávari do Nascimento, Gunta Gutmanis, Alexander de Andrade, Maria J. Calderan Rodrigues, Eduardo L.O. Camargo, Luis Felipe Boaretto, David H. Moon, Juliano Bragatto and Carlos A. Labate

Laboratório Max Feffer de Genética de Plantas, Departamento de Genética, Escola Superior de Agricultura "Luiz de Queiroz", Universidade de São Paulo, Piracicaba, SP, Brazil.

\begin{abstract}
UDP-glucose dehydrogenase (UGDH) catalyzes the oxidation of UDP-glucose (UDP-Glc) to UDP-glucuronate (UDP-GlcA), a key sugar nucleotide involved in the biosynthesis of plant cell wall polysaccharides. A full-length cDNA fragment coding for UGDH was cloned from the cambial region of 6-month-old $E$. grandis saplings by RT-PCR. The 1443-bp-ORF encodes a protein of 480 amino acids with a predicted molecular weight of $53 \mathrm{kDa}$. The recombinant protein expressed in Escherichia coli catalyzed the conversion of UDP-Glc to UDP-GIcA, confirming that the cloned cDNA encodes UGDH. The deduced amino acid sequence of the CDNA showed a high degree of identity with UGDH from several plant species. The Southern blot assay indicated that more than one copy of UGDH is present in Eucalyptus. These results were also confirmed by the proteomic analysis of the cambial region of 3-and 22-year-old E. grandis trees by 2-DE and LC-MS/MS, showing that at least two isoforms are present. The cloned gene is mainly expressed in roots, stem and bark of 6-month-old saplings, with a lower expression in leaves. High expression levels were also observed in the cambial region of 3- and 22-year-old trees. The results described in this paper provide a further view of the hemicellulose biosynthesis during wood formation in $E$. grandis.
\end{abstract}

Key words: UDP-glucose, UDP-glucuronate, hemicellulose, pectin, cell wall.

Received: July 7, 2009; Accepted: March 17, 2010.

\section{Introduction}

The biosynthesis of hemicelluloses and pectins in higher plants is mainly regulated by the cytosolic enzyme UDP-glucose dehydrogenase (UGDH) (EC 1.1.1.22), that catalyzes the sugar interconversion involving the fourelectron, $\mathrm{NAD}^{+}$-linked, oxidation of UDP-glucose to UDP-glucuronate (Amino et al., 1985; Gibeaut, 2000). The reaction is essentially irreversible, resulting in a unidirectional flow of UDP-glucuronate (UDP-GlcA) into a pool of sugar nucleotides, predominantly used for the biosynthesis of plant cell wall polysaccharides. UDP-GlcA is the precursor of many sugar nucleotides, including UDP-galacturonic acid (UDP-GalA), UDP-xylose (UDP-Xyl), UDP-arabinose (UDP-Ara) and UDP-apiose (UDP-Api), which are the substrates for the polymer synthases involved in the formation of pectins and hemicelluloses (Gibeaut and Carpita, 1994). UDP-glucuronate is the dominant sugar nucleotide precursor in the biosynthesis of hemicelluloses and pectins, providing half of the biomass of the primary cell wall

Send correspondence to Carlos A. Labate. Laboratório Max Feffer de Genética de Plantas, Departamento de Genética, Escola Superior de Agricultura "Luiz de Queiroz", Universidade de São Paulo, 13418-900 Piracicaba, SP, Brazil. E-mail: calabate @esalq.usp.
(Zablackis et al., 1995; Reiter and Vanzin, 2001; Seifert, 2004).

The presence of isoforms for UGDHs was ignored in previous studies (Tenhaken and Thulke, 1996; Stewart and Copeland, 1998; Seitz et al., 2000). In Arabidopsis, the $U G D H$ gene family is represented by four highly similar $U G D H$ isoforms: $U G D H 1$, earlier described by Seitz et al. (2000), and three others (UGDH2-4), located on distinct chromosomes (Reiter and Vanzin, 2001). More recently, a fifth $U G D H$ pseudogene (partial sequence) with a weaker similarity was detected (Klinghammer and Tenhaken, 2007). Moreover, in poplar, at least two isoforms were reported (Johansson et al., 2002). A developmentally regulated and often transient expression pattern for $U G D H$ transcripts was observed by Seitz et al. (2000), suggesting that the isoforms are expressed in cells only when sugar nucleotides derived from the UDP-GlcA are needed for the synthesis of new cell wall polymers. Developmental regulation was also suggested by Carvalho et al. (2008) in E. grandis wood-forming tissue, where one UGDH isoform is preferentially expressed.

The biosynthesis of UDP-GlcA in plants can also occur by the inositol oxygenation pathway. In young seed- 
lings, this alternative pathway operates and oxidizes inositol directly to GlcA, as shown by isotope-labeling experiments (Loewus et al., 1973; Roberts and Loewus, 1973; Sasaki and Taylor, 1984). The first irreversible step in the oxidation of myo-inositol is catalyzed by myo-inositol oxygenase (EC 1.13.99.1), generating D-glucuronate that is phosphorylated by D-glucuronokinase (EC 2.7.1.43) to Dglucuronate 1-P (Biswas et al., 1984), and immediately transformed into UDP-glucuronate by UDP-glucuronate1-phosphate uridylyltransferase (EC 2.7.7.44). Studies on enzymes participating in the sugar nucleotide interconversion showed that UGDH is often the least active enzyme of the pathway, and is also present in low amounts, leading to the conclusion that this enzyme might be rate-limiting for the synthesis of cell wall precursors, since there is a demand for UDP-glucuronate in all plant tissues and organs at all stages of development (Dalessandro and Northcote, 1977a,b; Robertson et al., 1995; Gibeaut, 2000).

In wood-forming tissues, the role of UGDH in the regulation of hemicellulose biosynthesis is still poorly understood, particularly in fast growing trees such as Eucalyptus spp. In the present study, we cloned a UGDHencoding cDNA from the cambial zone of 6-month-old $E$. grandis saplings and analyzed the expression pattern of transcripts from different developing tissues and plant ages by semi-quantitative RT-PCR. The cDNA sequences for $U G D H$ from woody species have previously been documented for poplar (Johansson et al., 2002) and cinnamon (NCBI, AY496079), and recently for Eucalyptus gunnii, although incomplete (EMBL, CT982226). Therefore, this is the first complete sequence of a $U G D H$ cDNA reported for E. grandis. Moreover, this work led to the conclusion, based on Southern blot analysis, that there are at least 2 copies of the $U G D H$ gene in $E$. grandis. We also isolated and identified three UGDH protein isoforms from the cambial region of 3- and 22-year-old trees, using 2-DE gels and LC-MS/MS.

\section{Material and Methods}

\section{Plant material}

Six-month-old saplings from a commercial clone of E. grandis, kindly provided by Suzano Papel e Celulose, were maintained in growth chambers under controlled conditions: $500 \mathrm{~mol} \mathrm{~m}^{-2} \mathrm{~s}^{-1}$ irradiance, $16 / 8 \mathrm{~h} \mathrm{light/dark} \mathrm{photo-}$ period, and a $24{ }^{\circ} \mathrm{C}$ day $/ 18{ }^{\circ} \mathrm{C}$ night temperature regime. The cambial region of 3- and 22-year-old-trees, containing the differentiating xylem and phloem tissues, was sampled by removing the bark and scrapping the inner parts of the stems with a razor blade, and immediately freezing it in liquid nitrogen, as described by Celedon et al. (2007).

\section{Design of degenerate primers}

The UGDH-encoding cDNA of E. grandis was cloned, using the RT-PCR technique employing degenerate primers to highly conserved 5' and 3'ends (Kunihiro et al., 2002). To accomplish this, a BLAST search (Altschul et al., 1977) was performed for plant orthologous sequences encoding UGDH protein. A preliminary analysis of the highly conserved $\mathrm{N}$ and $\mathrm{C}$ terminal regions among amino acid sequences of UGDH was made by means of the ClustalW2 program (Thompson et al., 1994), using soybean (AAB58398), Arabidopsis (BAB02581), rice (XP468764), cinnamon (AAR84297), poplar (AAF04455 and AAR32717), and taro (AA062313). The corresponding nucleotide sequences from soybean (U53418), Arabidopsis (AP001309), cinnamon (AY496079), poplar (AF0539973 and AY466400), taro (AY222335), rice (AK103919), wheat (BT009444) and maize (AY103689) were used to construct the degenerate primers flanking the $E$. grandis $U G D H$ ORF. The forward (5'ATGGTGAAGATHTGYT GYATY3') and reverse (5'TTADGCVAYVGCRGGCA TGTC3') primers were forced to flank the complete $U G D H$ open reading frame. The alignment of the 21 nucleotides from the 5'and 3' ends of the nine sequences showed that the differences among them were mainly in the third base of the codon, not changing the amino acid, with few exceptions (Figure 1). These minor differences were overcome by the use of degenerate primers. Primer sequences are represented in standard IUB/IUPAC amino acid and nucleic acid codes.

\section{Cloning and sequence analysis of the UGDH cDNA}

Total RNA was isolated from the cambial region of 6-month-old saplings of E. grandis using the method of Salzman et al. (1999), and poly(A) mRNA was purified from $75 \mu \mathrm{g}$ of total RNA, using the Dynabeads mRNA Purification kit (Dynal) as specified by the manufacturer, and eluted in $20 \mu \mathrm{L}$ Tris-HCl $10 \mathrm{mM}$.

A UGDH encoding cDNA was obtained by RT-PCR, using the SuperScript One-step RT-PCR with Platinum Taq (Invitrogen), and the specific flanking primers (UGDH_ Forward: 5'CACCATGGTGAAGATHTG YTGYATY3'; UGDH_Reverse: 5'TTADGCVAYVGCL GGCATGTC3') for the corresponding open reading frame. The directional sequence CACC was added to the sense primer to facilitate the cloning orientation of the cDNA. For cDNA synthesis, a $50 \mu \mathrm{L}$ RT-PCR reaction containing $25 \mu \mathrm{L}$ reaction mix $(0.4 \mathrm{mM}$ of each dNTP, $2.4 \mathrm{mM}$ of $\left.\mathrm{MgSO}_{4}\right), 100 \mathrm{pg}$ of mRNA, $0.2 \mu \mathrm{M}$ of each primer, and $1 \mu \mathrm{L}$ of RT/Platinum Taq mix was prepared. The cDNA was synthesized at $50{ }^{\circ} \mathrm{C}$ for $30 \mathrm{~min}$ and denatured at $94{ }^{\circ} \mathrm{C}$ for $2 \mathrm{~min}$, and amplification was performed using 38 cycles of $15 \mathrm{~s}$ at $94{ }^{\circ} \mathrm{C}, 30 \mathrm{~s}$ at $60^{\circ} \mathrm{C}, 1 \mathrm{~min}$ and $30 \mathrm{~s}$ at $72{ }^{\circ} \mathrm{C}$, followed by $7 \mathrm{~min}$ at $72^{\circ} \mathrm{C}$. The 1443 -bp blunt-end amplification product was cloned into the pENTR-DirectionalTOPO ${ }^{\circledR}$ Cloning Vector, for entry into the Gateway System (Invitrogen), according to the manufacturer's instructions. A $U G D H$ recombinant clone, selected in kanamycin 
(50 $\mu \mathrm{g} \mathrm{mL}^{-1}$ ), was purified and screened by PCR for the presence of full-length $U G D H$ cDNA, using degenerate primers and also by sequencing in both directions with the universal M13 primers and theBigDye Terminator Cycle sequencing kit (Perkin Elmer), to ensure the proper reading frame. The samples were loaded onto an ABI 3100 sequencer (Perkin Elmer). The complete nt sequence of the $E$. grandis $U G D H$ was deposited in the NCBI GenBank under accession $n^{\circ}$ EF179384.

\section{Expression of UGDH protein in E. coli}

The RT-PCR product corresponding to the $E$. grandis $U G D H$ cDNA was sub-cloned into the Gateway ${ }^{\circledR}$ pDEST17 vector (Invitrogen) in frame with a N-terminal 6x His tag, for expression of the recombinant protein, using the E. coli Expression System with Gateway ${ }^{\circledR}$ technology.

For the protein expression, the $U G D H$ recombinant pDEST17 vector was introduced into chemically competent $E$. coli $\mathrm{BL} 21-\mathrm{AI}$ (Invitrogen) by heat shock. A recombinant clone, previously screened by PCR for the presence of the $U G D H$ insert, was grown in LB medium containing ampicillin $\left(100 \mu \mathrm{g} \mathrm{mL}^{-1}\right)$ at $37{ }^{\circ} \mathrm{C}$ and $200 \mathrm{rpm}$. This starter culture $\left(1 \mathrm{~mL}, \mathrm{OD}_{600 \mathrm{~nm}}=0.7\right)$ was used to inoculate $50 \mathrm{~mL}$ of LB medium supplemented with ampicillin $\left(100 \mu \mathrm{g} \mathrm{mL}^{-1}\right)$ and left to grow at $37^{\circ} \mathrm{C}(200 \mathrm{rpm})$ until an $\mathrm{OD}_{600 \mathrm{~nm}}$ of 0.4 was reached. After $3 \mathrm{~h}$ of induction with $0.2 \%(\mathrm{w} / \mathrm{v}) \mathrm{L}$-arabinose, the bacterial cells were harvested by centrifugation at $13,000 \mathrm{~g}$ for $1 \mathrm{~min}$. The pellet was resuspended in $5 \mathrm{~mL}$ of lysis buffer $\left(100 \mathrm{mM} \mathrm{NaH} \mathrm{PO}_{4}, \mathrm{pH} 8.0 ; 10 \mathrm{mM}\right.$ Tris, containing $0.1 \%(\mathrm{w} / \mathrm{v})$ lysozyme, $1 \mathrm{mM}$ PMSF, $10 \mathrm{mM}$ B-mercaptoethanol, $10 \mu \mathrm{g}$ RNAseA $\mathrm{mL}^{-1}, 5 \mu \mathrm{g}$ DNAse $\mathrm{mL}^{-1}$ ) and sonicated (three times of 10-second bursts at medium intensity). The resulting lysate was separated into soluble and insoluble fractions by centrifugation $(3,000 \mathrm{~g})$ for $15 \mathrm{~min}$

\section{Purification of the recombinant protein}

The histidine fusion protein was purified from the soluble fraction using a purification column prepared with ProBondNickel-Chelating Resin (Invitrogen), according to the manufacturer's instructions. The purity and $M_{\mathrm{r}}$ of the proteins in the eluted fractions collected were analyzed by $12.5 \%(\mathrm{w} / \mathrm{v})$ SDS-PAGE, using Coomassie brilliant blue G-250 staining (Candiano et al., 2004).

Protein concentration was determined using the Bradford assay (Bradford, 1976) and bovine serum albumin as a standard with protein dye reagent (Bio-Rad), following the supplier's instructions.

\section{Enzyme assay}

The activity of the purified Poly-His-Tagged eucalyptus UDP-GDH was measured at $30{ }^{\circ} \mathrm{C}$ (Stewart and Copeland, 1999) in a continuous assay, by monitoring, with a Hitachi U3300 spectrophotometer, the increase in absorbance at $340 \mathrm{~nm}$ due to the UDP-Glc-dependent formation of NADH. Reaction mixtures for the standard assay contained, in a final volume of $1 \mathrm{~mL}, 20 \mathrm{mM}$ Tris-HCL, $\mathrm{pH}=8.0$, and $2 \mathrm{mM} \mathrm{MgCl}_{2}$. The kinetic data for $\mathrm{NAD}^{+}$or UDP-Glc as substrates were determined in triplicate assays, keeping one of the substrates at saturating concentrations. The assay was initiated by the addition of UDP-Glc, and activity was calculated from linear initial reaction rates, based on the assumption that 2 mol of NADH were formed per mole of oxidized UDP-Glc.

\section{Protein extraction for the two-dimensional gel electrophoresis}

Total proteins from the cambial region of 3- and 22-year-old $E$. grandis trees were extracted as described by Hurkman and Tanaka (1986), with few modifications introduced by Celedon et al. (2007).

\section{Two-dimensional gel electrophoresis}

Protein samples (containing $2 \mu \mathrm{g}$ of protein $\mu \mathrm{L}^{-1}$ ) were applied onto a 4-7 linear immobilized $\mathrm{pH}$ gradient strip (18 cm, GE HealthCare) and focalized using the IPGphor apparatus (GE HealthCare). Strips were rehydrated for $12 \mathrm{~h}$ at $20{ }^{\circ} \mathrm{C}$ and $50 \mathrm{~V}$. The proteins were prefocused at $100 \mathrm{~V}$ for $1 \mathrm{~h}$ and then at $200 \mathrm{~V}$ for $1 \mathrm{~h}, 400 \mathrm{~V}$ for $1 \mathrm{~h}, 700 \mathrm{~V}$ for $1 \mathrm{~h}, 1000 \mathrm{~V}$ for $1 \mathrm{~h}$, and finally focused for a total of $70 \mathrm{KVh}$. After isoeletric focusing (IEF), the strips were kept at $-80{ }^{\circ} \mathrm{C}$ until needed.

For the second-dimension analysis, the strips were kept at room temperature for $15 \mathrm{~min}$ in equilibration buffer [6 M urea, 2\% (w/v) SDS, $50 \mathrm{mM}$ Tris-HCl pH 6.8, 30\% (v/v) glycerol] containing 1\% (w/v) DTT, followed by incubation in the same buffer added with $2.5 \%(\mathrm{w} / \mathrm{v})$ iodoacetamide and $0.001 \%$ bromophenol blue. The seconddimension electrophoresis was performed in $12 \%(\mathrm{w} / \mathrm{v})$ polyacrylamide gels at $30 \mathrm{~mA}$, until the dye reached the bottom of the gel. Three replicates were performed for each sample. Proteins were detected using Coomassie Brilliant Blue G-250 (Candiano et al., 2004), with modifications. Gels were incubated twice for $1 \mathrm{~h}$ each in a solution containing 3\% (v/v) phosphoric acid and $50 \%(\mathrm{v} / \mathrm{v})$ ethanol, and once for $1 \mathrm{~h}$ in $2 \%(\mathrm{v} / \mathrm{v})$ phosphoric acid. Protein detection was done after leaving the gels overnight in staining solution $[17 \%(\mathrm{v} / \mathrm{v})$ methanol, $15 \%(\mathrm{w} / \mathrm{v})$ ammonium sulfate, $2 \%(\mathrm{v} / \mathrm{v})$ phosphoric acid plus $0.1 \%(\mathrm{w} / \mathrm{v})$ dye], followed by 3 washes in water (10 min each). The gels were then stored in $15 \%(\mathrm{w} / \mathrm{v})$ ammonium sulfate for image analysis and spot selection.

\section{In-gel protein digestion}

Protein spots were excised from SDS-PAGE gels, cut into $1 \mathrm{~mm}$ cubes and washed with water for $15 \mathrm{~min}$. For destaining, the gel pieces were washed several times with a $50 \%(\mathrm{v} / \mathrm{v})$ acetonitrile $(\mathrm{ACN})$ solution containing $50 \mathrm{mM}$ ammonium bicarbonate, until complete removal of the Coomassie (G250) stain. The 2-DE gel spots were com- 


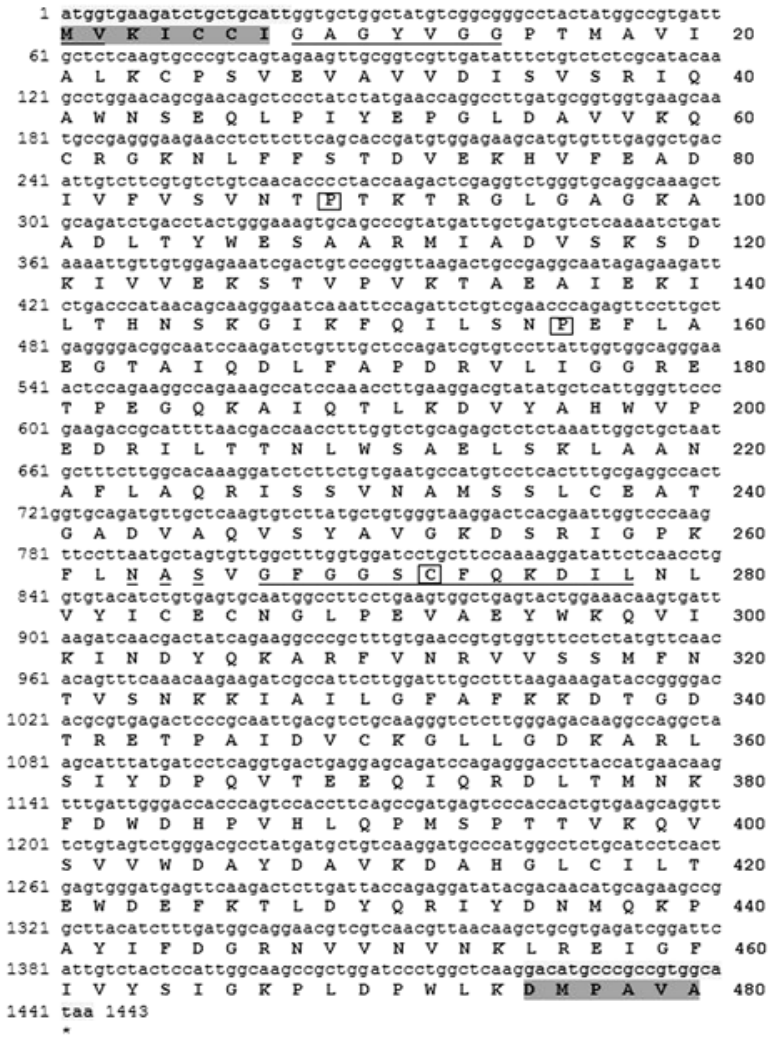

Figure 1 - Nucleotide (nt) and derived amino acid (aa) sequence of the cloned cDNA of the E. grandis $U G D H$ gene. Underlined are the translation initiation nt motif (aa\# 1 and 2), the NAD cofactor binding site (aa\# 8-14) and the catalytic site (aa\# 267-278, with a Cys residue, boxed). A putative glycosylation site (aa\# 263-265) is underlined with a broken line. Pro residues at 89 and 156 are also boxed. The conserved $\mathrm{N}$ and $\mathrm{C}$ terminal regions (highlighted in dark grey) were used for the alignment of the 21 nucleotides from the 5'and 3'-ends (highlighted in light grey) of the cloned cDNA against poplar (AF053973 and AY466400), soybean (U53418), Arabidopsis (AP001309), taro (AY222335), cinnamon (AY496079), rice (AK103919), wheat (BT009444) and maize (AY103689), to produce the degenerate primers. The complete nt-sequence of $E$. grandis $U G D H$ was deposited in the NCBI GenBank under accession $\mathrm{n}^{\circ}$ EF179384.

pletely dehydrated with $100 \%$ (v/v) ACN for 10 min, rehydrated with $50 \mathrm{mM}$ ammonium bicarbonate plus $20 \mathrm{mM}$ dithiothreitol (DTT), and maintained for $40 \mathrm{~min}$ at $60^{\circ} \mathrm{C}$. This solution was discarded and replaced by $50 \mathrm{mM}$ ammonium bicarbonate with $55 \mathrm{mM}$ iodoacetamide, before keeping the tubes in darkness for $30 \mathrm{~min}$. Then the gel pieces were dehydrated again with $100 \%(\mathrm{v} / \mathrm{v}) \mathrm{ACN}$ and let to air-dry for complete removal of the solvent. Protein digestion was carried out with a solution of $10 \mathrm{ng} \mu \mathrm{L}^{-1} 1$ trypsin (Promega) in $25 \mathrm{mM}$ ammonium bicarbonate, for $12 \mathrm{~h}$ at $37^{\circ} \mathrm{C}$. Gel pieces were extracted twice with $50 \mu \mathrm{L}$ of $60 \%$ $(\mathrm{v} / \mathrm{v}) \mathrm{ACN}$ containing $1 \%(\mathrm{v} / \mathrm{v})$ formic acid (FA), and once with $50 \mu \mathrm{L}$ of $100 \% \mathrm{ACN}$. All supernatants were combined and vacuum-dried. The peptides were then resuspended in $12 \mu \mathrm{L} 1 \%(\mathrm{v} / \mathrm{v}) \mathrm{FA}$ for MS analysis.

\section{Protein identification by LC-MS/MS}

The peptides were separated and identified by on-line chromatography, using a Cap-LC coupled to a Q-TOF Ultima API mass spectrometer (Waters, UK). $5 \mathrm{~mL}$ of sample were loaded onto a $0.18 \mathrm{~mm}$ x $23.5 \mathrm{~mm}$ NanoEase Trapping Column (Waters, UK) for pre-concentration and desalination, followed by peptide separation on a $\mathrm{C} 18,3.5 \mu \mathrm{m}$, $75 \mu \mathrm{m}$ x $100 \mathrm{~mm}$ NanoEase Symmetry 300 LC column (Waters, UK). Peptides were eluted in a 60 min linear gradient of solvent B $[95 \%(\mathrm{v} / \mathrm{v})$ ACN containing $0.1 \%(\mathrm{v} / \mathrm{v})$ formic acid in water] and solvent A [5\% (v/v) ACN containing $0.1 \%(\mathrm{v} / \mathrm{v})$ formic acid in water], at a flow rate of $250 \mathrm{~nL} \mathrm{~min}^{-1}$.

\section{MS spectra analysis}

All analyses were performed using a positive ion mode at a $3 \mathrm{kV}$ needle voltage. The mass range was set from 300 to $2000 \mathrm{~m} / \mathrm{z}$, and the MS/MS spectra acquired for the most intense peaks ( $\geq 15$ counts). Multiple charged precursor ions were selected for fragmentation and peptide sequencing, using automated data-dependent-acquisition (DDA) MassLynx software (Waters), switching from the MS to the MS/MS mode and then returning to MS. The resulting fragmented spectra were processed using the ProteinLynx v. 4.0 software (Waters), and the MASCOT MS/MS Ion Search was used to blast the sequences against the SwissProt and NCBI databank. Combined MS-MS/MS searches were conducted with parent ion mass tolerance at $50 \mathrm{ppm}, \mathrm{MS} / \mathrm{MS}$ mass tolerance of $0.1 \mathrm{Da}$, carbamidomethylation of cysteine (fixed modification) and methionine oxidation (variable modification). According to MASCOT probability analysis, only significant hits $(\mathrm{p}<0.05)$ were accepted.

\section{Southern blot analysis}

Genomic DNA $(15 \mu \mathrm{g})$ was isolated from Eucalyptus grandis leaves, as described by Doyle and Doyle (1987), and digested with HindIII, EcoRI, BamHI, EcoRV, NcoI and $\mathrm{SacI}$ restriction enzymes at $37^{\circ} \mathrm{C}$ for $16 \mathrm{~h}$. The DNA fragments were separated on $1 \%(\mathrm{w} / \mathrm{v})$ agarose gel in $0.5 \mathrm{x}$ TBE buffer (45 mM Tris-borate, $1 \mathrm{mM}$ EDTA, $\mathrm{pH} 8.0$ ), stained with ethidium bromide, visualized under ultraviolet light, and denaturated before being transferred onto a Hybond $\mathrm{N}^{+}$nylon membrane (GE HealthCare) by capillary transfer (Southern, 1975; Sambrook et al., 1989). The membrane was probed using the AlkPhos Direct Labeling Module (GE HealthCare). The alkaline-phosphataselabeled-PCR product (698-bp) resulting from the amplification of a conserved internal region (nt\# 188-886, Figure 1) of the eucalyptus cDNA (1443-bp) cloned with the following primers (ugdhDForward: 5'-GAAGAACCTCTT CTTCAGCA-3' ugdhDReverse: 5'-AGTACTCAGCCAC TTCAGGA-3') synthesized for the UGDH domain (pfam03721, pfam00984, pfam03720), used as probe, was 
detected with the Gene Images CDP-Star Detection Module (GE HealthCare). Hybridization was carried out at $60{ }^{\circ} \mathrm{C}$ for $16 \mathrm{~h}$, followed by stringent washes: twice in fresh primary wash buffer [2 $\mathrm{M}$ urea, $50 \mathrm{mM} \mathrm{NaH} \mathrm{PO}_{4}, \mathrm{pH} 7.0$, $150 \mathrm{mM} \mathrm{NaCl}, 1 \mathrm{mM} \mathrm{MgCl}{ }_{2}$ containing $0.1 \%$ (w/v) SDS and $0.2 \%(\mathrm{w} / \mathrm{v})$ blocking reagent] at $55^{\circ} \mathrm{C}$ for $10 \mathrm{~min}$, and once in secondary wash buffer [ $50 \mathrm{mM}$ Tris, $100 \mathrm{mM} \mathrm{NaCl}$ containing $2 \mathrm{mM} \mathrm{MgCl}_{2}$ ] at room temperature for $5 \mathrm{~min}$. The hybridization signal was recorded on X-ray film (MXG/PLUS, Kodak) after $1 \mathrm{~h}$ exposure between intensifying screens (GE HealthCare), at room temperature.

The resulting exposed X-ray film was used as reference for localization of the bands.

\section{Semi-quantitative real-time PCR (RT-PCR)}

Tissue samples from 6-month-old saplings and from 3and 22-year-old plants were used for total RNA isolation, as described by Salzman et al. (1999). Poly(A) mRNAs were purified from $75 \mu \mathrm{g}$ of total RNA, using the Dynabeads mRNA Purification kit (Dynal) as specified by the manufacturer, and eluted in $20 \mu \mathrm{L}$ Tris- $\mathrm{HCl} 10 \mathrm{mM}$. First-strand cDNAs were generated using the SuperScript III FirstStrand Synthesis SuperMix in a $20 \mu \mathrm{L}$ reaction mixture, containing $3 / 10$ of the eluted mRNA, $50 \mathrm{ng}$ random hexamers, and $1 \mu \mathrm{L}$ annealing buffer. After $5 \mathrm{~min}$ of incubation at $65^{\circ} \mathrm{C}, 10 \mu \mathrm{L}$ of $2 \mathrm{x}$ First-Strand Reaction Mix plus $2 \mu \mathrm{L}$ SuperScript III/RNase OUT Enzyme Mix, which includes the SuperScript III Reverse Transcriptase, were added, and the final reaction mixture was incubated for $10 \mathrm{~min}$ at $25^{\circ} \mathrm{C}$, followed by $50 \mathrm{~min}$ at $50^{\circ} \mathrm{C}$, and $5 \mathrm{~min}$ at $85^{\circ} \mathrm{C}$, following the manufacturer's instructions (Invitrogen). Semi-quantitative RT-PCR assays were performed, using $1 / 10$ of the cDNA preparation per PCR, based on a preliminary semi-quantitative RT-PCR (data not shown). Primer sequences and amplicon sizes were the following: $U G D H$ (247-bp; primers designed specifically for the cloned eucalyptus cDNA forward 5'- GCCCGTATGATTGCTGATGTC -3', reverse 5'TCAAGGTTTGGATGGCTTTC-3'); ubiquitin (223-bp, primers to the $E$. grandis constitutive ubiquitin gene, forward 5'-CGATTGATTCTCAGCAAGC-3', reverse 5'GGATGTTGTAGTCAGCCAAGG-3'). Amplification specificity was checked by melting-curve analysis, and PCR efficiency determined using standard curves for each primer pair constructed with serial dilutions $(1: 10,1: 100$ and $1: 1000)$ of the cDNA preparation.

\section{Results and Discussion}

\section{PCR amplification of the full-length cDNA encoding E. grandis UGDH}

In this study, the degenerate primers designed to anneal highly conserved 5' and ' ' regions of already known genes, in combination with the RT-PCR technique, proved to be a potential strategy to overcome the difficulties in cloning a particular novel gene, when cDNA or a genomic library are not available. The RT-PCR reaction produced a 1443-nt-long cDNA sequence, with an open reading frame of 480 amino acids encoding UGDH (Figure 1).

\section{Nucleotide and deduced amino acid sequence analysis}

The deduced amino acid sequence for eucalyptus shows conserved motifs (pfam03721, pfam00984, pfam03720). Figure 1 (underlined) presents the translation initiation nt motif (aa\# 1 and 2), the NAD cofactor binding site (aa\# 8-14), the catalytic site (aa\# 267-278, with a Cys residue, boxed). A putative glycosylation site (aa\# 263-265), also found in poplar (Johansson et al., 2002), is indicated with a broken line, and Pro residues at aa\# 89 and 156 are also boxed, representing the main chain bends in the protein structure (Hempel et al., 1994). The derived amino acid sequence from the database search BLASTX analysis (Altschul et al., 1997) showed a high degree of identity to the UGDH of soybean (92\%), cinnamon (90\%), Arabidopsis $(90 \%)$, taro $(89 \%)$, poplar $(89 \%)$, and rice $(85 \%)$, among several plant species, including some putatives UDP-glucose dehydrogenases, such as that of tobacco (91\%). The high identity among UGDHs of higher plants suggests strict structural requirements for proper functioning of the protein. It is interesting to observe the high degree of amino acid sequence identity of the eucalyptus UGDH, even along the $\mathrm{N}$ and $\mathrm{C}$ terminal regions (Figure 1, highlighted in dark grey), where the differences in the first 25 aa, were less than $4 \%$ and $16 \%$, respectively, compared to the leguminosa soybean and gramineae such as rice, maize and, particularly, wheat. The analysis of the phylogenetic tree, generated using the CLC Main Work Bench 5.5 (UPGMA algorithm with Bootstrap analysis, 100 replicates) for the eucalyptus UGDH protein sequence and eight other plant species, shows a high similarity of the $E$. grandis protein sequence to various plant sequences, particularly soybean and Arabidopsis (Figure S1, supplementary data).

\section{Expression of recombinant eucalyptus UGDH}

The recombinant UGDH has been found to be often present in protein inclusion bodies (Tenhaken and Thulke, 1996; Hinterberg et al., 2002). It is known that eukaryotic proteins expressed in E. coli often form protein inclusion bodies, due to differences in the protein-folding systems between prokaryotes and eukaryotes (Oka and Jigami, 2006). Therefore, polyhistidine recombinant eucalyptus UGDH protein was produced in BL21-AI cells, and purified under a narrow range of optimized conditions, which included a low centrifugation of the lysate to recover, under native conditions, enough enzymatically active protein in the soluble fraction. The protein was purified at $4{ }^{\circ} \mathrm{C}$, and immediately used for the enzyme assay.

The Coomassie-stained SDS-PAGE gel illustrates the $\mathrm{L}$-arabinose induction of the UGDH recombinant protein in 
E. coli (Figure 2). The identification of the protein was confirmed by LC-MS/MS, and the peptides sequenced covered $23.33 \%$ of the total protein, with an estimated molecular weight of $52.91 \mathrm{kDa}$, and a $100 \%$ probability that the peptides are related to the expected protein (Table S1, supplementary data).

The activity of the purified Poly-His-Tagged-UGDH measured at $30{ }^{\circ} \mathrm{C}$ (Stewart and Copeland, 1999), in a continuous assay, by spectrophotometrically monitoring the absorbance increase at $340 \mathrm{~nm}$ due to the UDP-Glcdependent formation of NADH, showed that the recombinant protein expressed in E. coli catalyzed the conversion of UDP-Glc to UDP-GlcA (Figure 3), thus confirming that the cloned cDNA encodes the UGDH enzyme.

\section{Enzyme kinetics}

The recombinant protein expressed in E. coli catalyzed the conversion of UDP-Glc to UDP-GlcA, confirming that the cloned cDNA encodes the UGDH enzyme (Figure 3). The kinetic data were then fitted to the Michaelis-Menten equation to obtain the $K_{\mathrm{m}}$ and $V_{\max }$ values (Segel, 1976). For both substrates, UDP-Glc and NAD ${ }^{+}$, hyperbolic saturation curves were observed and the $K_{\mathrm{m}}$ values calculated, using the Origin-software ${ }^{\circledR}, 60.7 \pm 8.5 \mu \mathrm{M}$ for UDP-Glc $\left(V_{\max }=67.9 \pm 9.2 \mu \mathrm{mol} \mathrm{min}^{-1} \mathrm{mg}\right.$ protein $\left.{ }^{-1}\right)$ and $67.3 \pm 17.9 \mu \mathrm{M}$ for $\mathrm{NAD}^{+}\left(V_{\max }=171.8 \pm 34.8 \mu \mathrm{mol}\right.$ $\min ^{-1} \mathrm{mg}$ protein $^{-1}$ ) (Figures 3A and 3B, respectively). The estimated $K_{\mathrm{m}}$ of the eucalyptus enzyme for $\mathrm{NAD}^{+}$was similar to the value described for the recombinant protein from soybean $(70 \pm 5 \mu \mathrm{M})$, whereas the $K_{\mathrm{m}}$ for UDP-Glc was around 3 times higher $(22 \pm 2 \mu \mathrm{M})$ (Hinterberg et al., 2002). A characterization of three isoforms of UGDH (UGDH2, UGDH3 and UGDH4) from Arabidopsis evidenced a similar affinity value for the cofactor $\mathrm{NAD}^{+}$as that observed for eucalyptus (40-45 $\mu \mathrm{M})$, while major differences were observed in the $K_{\mathrm{m}}$ for UDP-Glc: $123 \pm 9 \mu \mathrm{M}, 335 \pm 16 \mu \mathrm{M}$ and $171 \pm 9 \mu \mathrm{M}$, respectively (Klinghammer and Tenhaken, 2007). The high affinity of the enzyme for $\mathrm{NAD}^{+}$was also observed in eucalyptus, confirming previous observations that the UGDHs are not limited by $\mathrm{NAD}^{+}$levels in vivo, while UDP-Glc affinity might be isoform-dependent (Hinterberg et al., 2002; Klinghammer and Tenhaken, 2007).

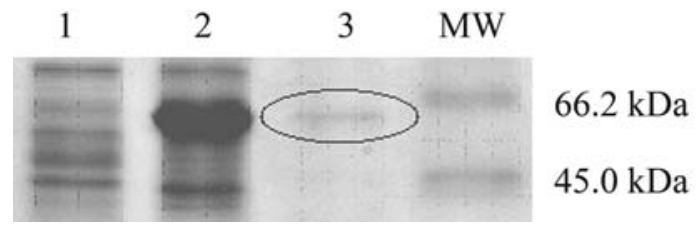

Figure 2 - Coomassie-stained SDS-PAGE of recombinant UGDH protein. The eucalyptus $U G D H$ cDNA cloned into a His-tagged pDEST expression vector was used to transform the BL21 E. coli cells. (1) Extracts from uninduced cells; (2) L-arabinose-induced cells; and (3) the purified recombinant eucalyptus UGDH from the L-arabinose-induced $E$. coli culture. MW: Molecular weight marker (Sigma).
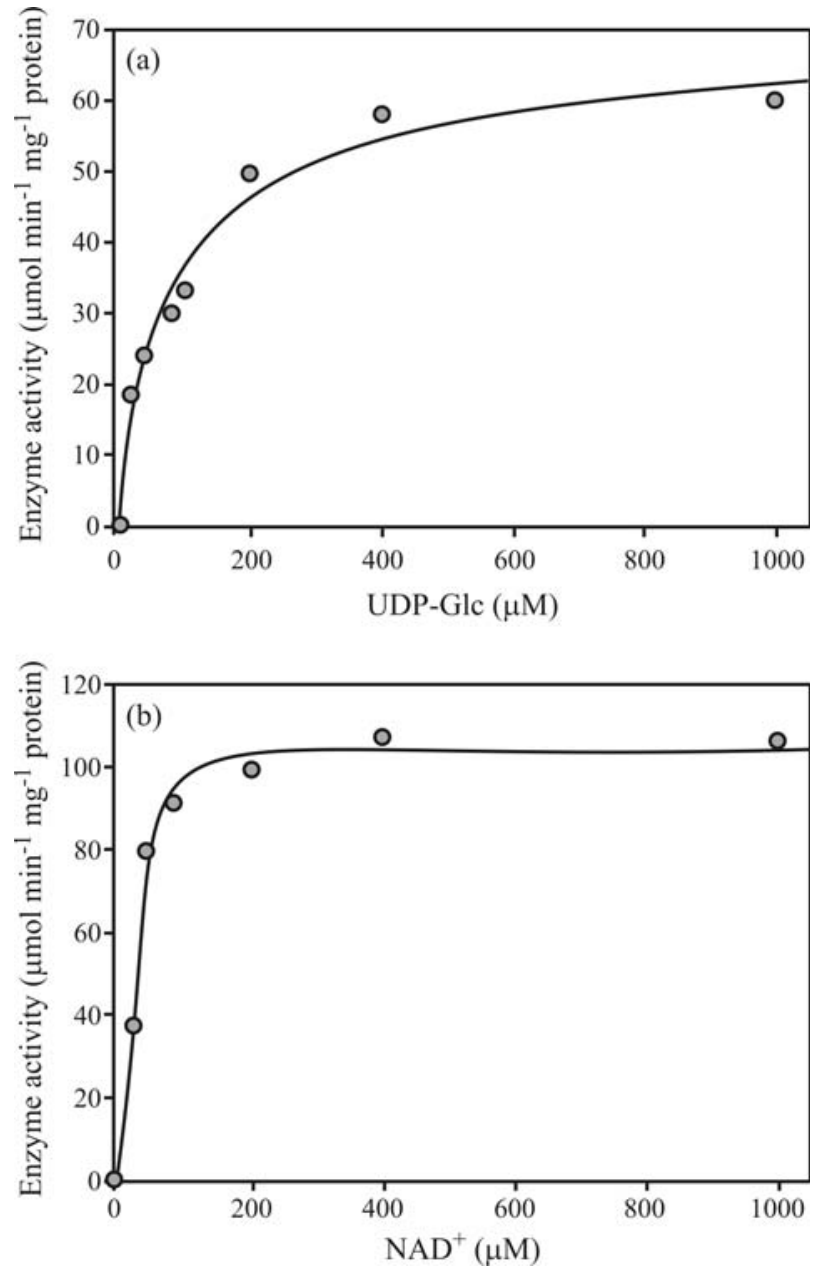

Figure 3 - Kinetic data of the eucalyptus UDP-GlucDH. The steady-state enzyme activity was measured as conversion of $\mathrm{NAD}^{+}$to $\mathrm{NADH}$ detected by the absorbance at $340 \mathrm{~nm}$. Purified eucalyptus UDP-GlucDH was incubated for 1 min with increasing concentrations of $\operatorname{NAD}^{+}(0-1 \mathrm{mM})$ in the presence of saturating substrate (A, UDP-Gluc, $1 \mathrm{mM}$ ), or with increasing concentrations of UDP-Gluc ( $0-1 \mathrm{mM})$ in the presence of saturating cofactor $\left(\mathrm{B}, \mathrm{NAD}^{+}, 1 \mathrm{mM}\right)$.

\section{Genomic copies of $U G D H$}

Southern blot analysis indicated the existence of a least two copies of the $U G D H$ gene within the eucalyptus genome (Figure 4). The existence of a single-copy $U G D H$ gene has been described for soybean (Tenhaken and Thulke, 1996) and Arabidopsis (Tenhaken and Thulke, 1996; Seitz et al., 2000). In poplar (Johansson et al., 2002), two highly homologous genes were found, as also observed in maize (Kärkönen et al. 2005). However, a later evaluation of the Arabidopsis and poplar genome projects indicated multiple copies. The presence of four UGDH isoforms in Arabidopsis, highly similar to each other, reported by Reiter and Vanzin (2001), was confirmed by Klinghammer and Tenhaken (2007), who found a fifth $U G D H$ pseudogene, located on chromosome III, with a weaker similarity to the others. In the Populus trichocarpa genome (Populus genome project), four $U G D H$ genes were identified, one in 


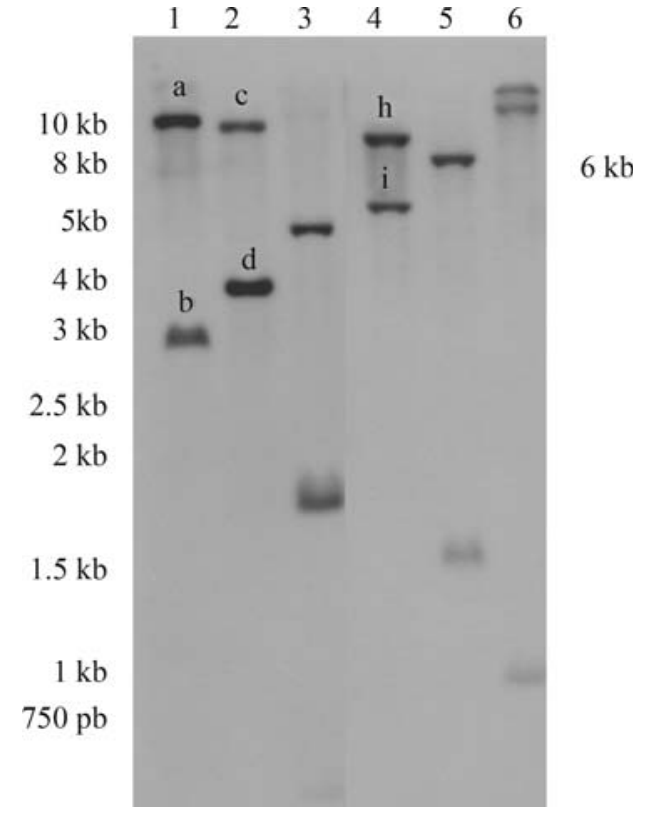

Figure 4 - Genomic Southern blot of E. grandis DNA, restricted with HindIII (1), EcoRI (2), BamHI (3), EcoRV (4), NcoI (5), and SacI (6). The sizes of the fragments are indicated in kilobase pairs $(\mathrm{kb})$. The alkaline-phosphatase-labeled PCR product (698-bp) resulting from the amplification of a conserved internal region (nt\# 188-886, Figure 1) of the cloned E. grandis cDNA (1443-bp) was used as probe.

linkage group IV (224080232), one in linkage group VIII (224098951), one in linkage group X (224112137), and one in linkage group XVII (224141486).

We further analyzed the possible number of copies for $U G D H$ in the Eucalyptus genome by performing a tblastx analysis of the eucalyptus ESTs sequences available in the GenBank database. The results showed that the cloned $U G D H$ sequence from $E$. grandis is highly similar $(\sim 99 \%)$ to the amino acid sequences of seven ESTs produced from the differentiating xylem of Eucalyptus gunnii (103476385, 103475842, 103479156, 103478292, 103476672, 103476952, 103480206) and five Eucalyptus globulus EST sequences, using mRNA isolated from leaf tissue under low temperature conditions (162324959, 162326130, 162329222, 162329166, 162326954). The phylogenetic tree generated using CLC Main Work Bench 5.5 (UPGMA algorithm with Bootstrap analysis, 100 replicates) for the complete nucleotide sequence of the cloned $E$. grandis UGDH mRNA (144926038) with these seven cambial E. gunnii EST and the five leaf E. globulus sequences (Figures 5A and 5B, respectively), suggests that there are at least two groups of nucleotide sequences, most probably indicating two isoforms of this gene in the RNA extracted from the cambial and leaf tissues.

The amplification product obtained from the eucalyptus genomic DNA against the primers flanking the $U G D H$ open reading frame, corresponds exactly to the same size (1443-bp) of the eucalyptus UGDH cDNA (Figure 6), showing the lack of introns along the cloned $U G D H$ gene

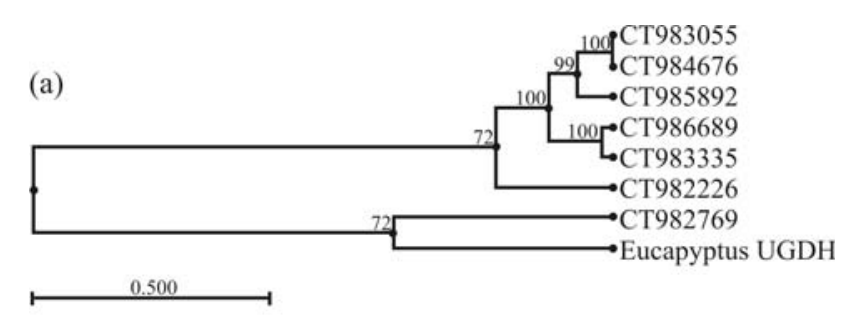

(b)

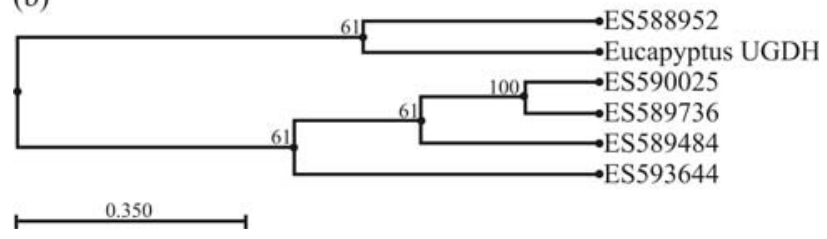

Figure 5 - Phylogenetic tree generated using CLC Main Work Bench 5.5 (UPGMA algorithm with Bootstrap analysis, 100 replicates) for the complete nucleotide sequence of the cloned E. grandis $U G D H$ mRNA (144926038): A) using seven E. gunnii EST sequences (103476385, 103475842, 103479156, 103478292, 103476672, 103476952, 103480206) of mRNA isolated from differentiating xylem; B) using five E. globulus EST sequences (162324959, 162326130, 162329222, $162329166,162326954)$ of mRNA isolated under low temperature conditions from leaf tissue.

sequence. The restriction map of the UGDH ORF (Figure S2, supplementary data) shows that the restriction enzymes EcoRI, HindIII and EcoRV do not cut the cloned fragment internally. This indicates that the bands observed in the Southern blot assay (Figure 4, lanes 1,2 and 4), which are all larger than $1.6 \mathrm{~kb}$, most probably contain the complete cloned $U G D H$ ORF.

Moreover, in order to investigate the existence of UGDH protein isoforms, we produced 2DE-PAGE gels with proteins isolated from the cambial region of 3-and 22 -year-old E. grandis trees. Figure 7 shows the identification of three distinct spots $(1,2$ and 3$)$ with the peptide data used to identify the proteins shown in Table S2 (supplementary data). Spot 3 showed a $M_{\mathrm{r}}$ of $\sim 53.0 \mathrm{kDa}$ and a $\mathrm{pI}$ of approximately 6.5 , which is in accordance with the calculated values for the $M_{\mathrm{r}}$ and $\mathrm{pI}$ of the cloned sequence (53.09 $\mathrm{kDa}$ and 6.52 , respectively). These values are similar to those obtained for soybean $(52.94 \mathrm{kDa}$ and 5.81$)$ and poplar (52.99 kDa and 6.20). Thus, spots 1 and 2 represent proteins with different characteristics (lower $\mathrm{pI}$ and lower $M_{\mathrm{r}}$ ), indicating the existence of at least one more copy of $U G D H$ in the E. grandis genome. The differences between spots 1 and 2 might be explained by posttranslational modification, such as phosphorylation, although further analysis is needed to confirm this hypothesis.

UGDH expression in different tissues of 6-month-old saplings and in the cambial region of juvenile and mature E. grandis wood

The expression of $U G D H$ in different tissues of 6month-old saplings and in the cambial region of 3- and 22- 


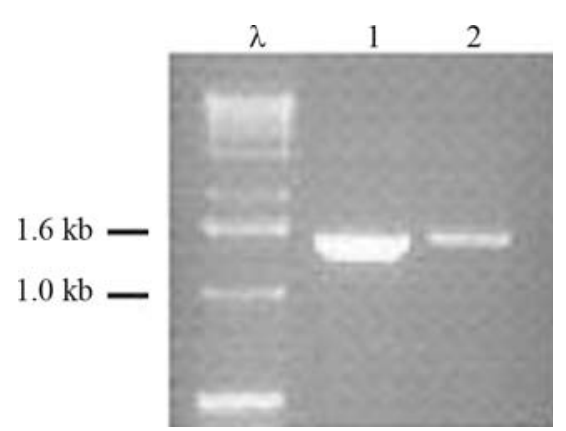

Figure 6 - Amplification product (1443-bp) of the eucalyptus genomic DNA (1), and the corresponding cDNA (2) for eucalyptus $U G D H$, against the degenerate primers flanking the $U G D H$ open reading frame. $\lambda: 1 \mathrm{~kb}$ DNA ladder (Invitrogen), kb: kilobase pair.

year-old trees was analyzed by semi-quantitative RT-PCR. In the 6-month-old saplings the maximum expression was observed in roots, whereas in stem and bark it was intermediate, and the leaves displayed the lowest expression (Figure 8). Similar results were observed in tobacco plants by Bindschedler et al. (2005), who compared the expression of $U G D H$ and NtADH2 (the dual specific $U G D H$ similar to $A D H$ ), suggesting that the isoforms of $U G D H$ might be preferentially involved in primary rather than in secondary growth, since they were strongly expressed in roots and in the youngest internodes of the stem, with the lowest level of expression observed in buds and in tobacco leaves, similar to the expression pattern observed by Seitz et al. (2000) in Arabidopsis.

We then checked the role of $U G D H$ in the woodforming tissues of juvenile and mature trees, by comparing the level of expression relative to the stem of 6-month-old saplings. Figure 9 shows that the expression of $U G D H$ in the cambial region of 3- and 22-year-old trees was significantly higher than in the stem of 6-month-old saplings, indicating that the enzyme may have an important role in controlling hemicellulose biosynthesis during wood formation.

In this study, the strategy of using degenerate primers in combination with the RT-PCR technique, proved to be

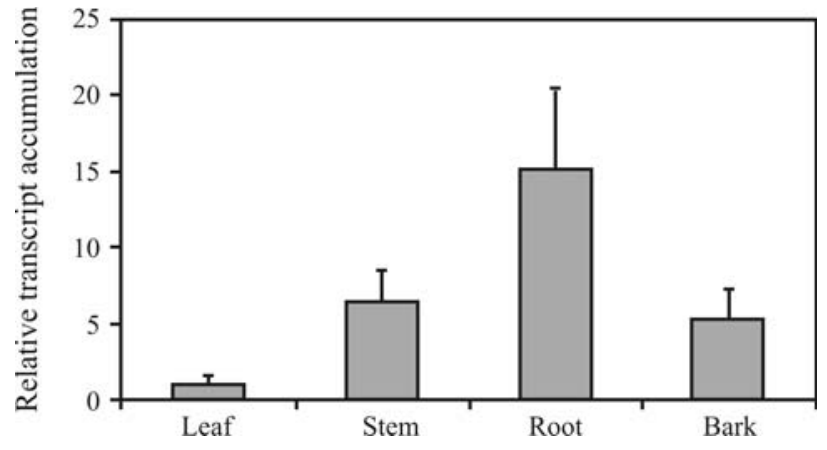

Figure 8 - Semi-quantitative RT-PCR of $U G D H$ transcript accumulation in roots, stem, bark and leaves of 6-month-old E. grandis saplings. Transcript levels were normalized relative to the ubiquitin expression level as internal standard. Results are expressed as mean of three replicates and standard deviation relative to the leaf expression level, to which the value 1 on the linear scale was assigned.

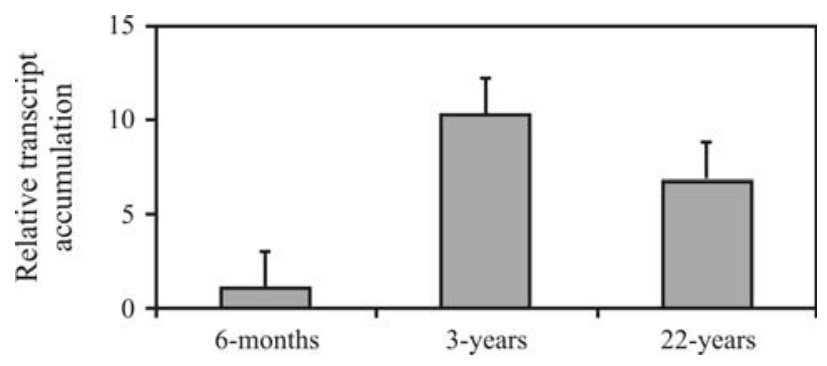

Figure 9 - Semi-quantitative RT-PCR of $U G D H$ transcript accumulation of the cambial region from 3- and 22-year-old E. grandis trees. Transcript levels were normalized relative to the ubiquitin expression level as internal standard. Results are expressed as mean of three replicates and standard deviation relative to the stem expression level of the 6-month-old $E$. grandis saplings, to which the value 1 on the linear scale was assigned.

efficient to overcome the difficulties in cloning a particular novel gene, when cDNA or a genomic library are not available. We were able to clone and express the recombinant UGDH protein of E. grandis and to confirm its activity and sequence. The role of UGDH in wood-forming tissues is still poorly understood, and the isolation of E. grandis cDNA offers an opportunity to further understand the importance of this enzyme in trees.
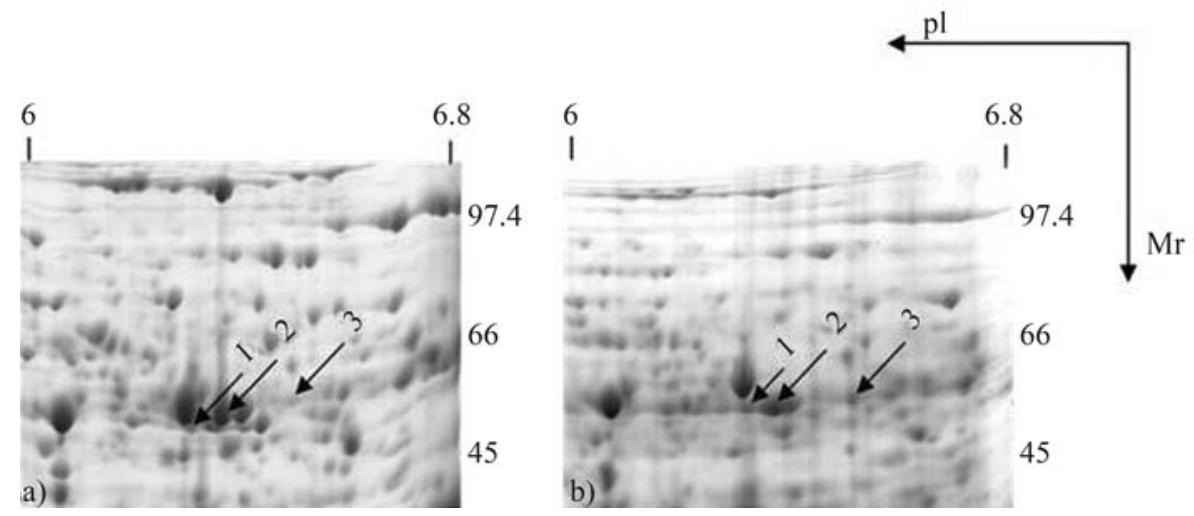

Figure 7 - 2-DE gels from the cambial region of 3-year-old (A) and 22-year-old (B) E. grandis trees. Arrows indicate the spot numbers of UGDH isoforms. Ip: Isoeletric-point, $M_{\mathrm{r}:}$ Molecular weight in kiloDaltons $(\mathrm{kDa})$. 


\section{Acknowledgments}

This work was financially supported by the Innovation Technology Program funded by FAPESP (01/110808) and Suzano Papel e Celulose S.A. Further support was provided by MEC-CAPES with fellowships to Daniela Defávari do Nascimento and Gunta Gutmanis, CNPq with fellowship to Alexander de Andrade, and by FAPESP with fellowships to Ana Letícia Ferreira Bertolo, Luis Felipe Boaretto and Eduardo Leal de Oliveira Camargo. We would like to thank Dr. Siu Mui Tsai and Fabiana Cannavan from CENA/ESALQ/USP and Dr Maria Helena de Souza Goldman and Andrea Carla Quiapim from FFCLRP/USP, for their help with DNA sequencing. We would also like to thank Livia M. Franceschini for helping with the configuration of all figures.

\section{References}

Altschul SF, Madden TL, Schaffer AA, Zhang J, Zhang Z, Miller WE and Lipman DJ (1997) Gapped BLAST and PSIBLAST: A new generation of protein database search programs. Nucleic Acids Res 25:3389-3402.

Amino S, Takeuchi Y and Komamine A (1985) Changes in enzyme activities involved in formation and interconversion of UDP-sugars during the cell cycle in a synchronous culture of Catharanthus roseus. Physiol Plant 64:111-117.

Bindschedler LV, Wheatley E, Gay E, Cole J, Cottage A and Bolwell GP (2005) Characterisation and expression of the pathway from UDP-glucose to UDP-xylose in differentiating tobacco tissue. Plant Mol Biol 57:285-301.

Biswas BB, Ghosh B and Majumder AL (1984) myo-Inositol polyphosphates and their role in cellular metabolism: A proposed cycle involving glucose-6-phosphate and myo-inositol phosphates. In: Roodyn DB (ed) Subcellular Biochemistry. Plenum, London, pp 237-280.

Bradford MM (1976) A rapid and sensitive method for the quantitation of microgram quantities of protein utilizing the principle of protein-dye binding. Anal Biochem 72:248-254.

Candiano G, Bruschi M, Musante L, Santucci L, Ghiggeri GM, Carnemolla B, Orecchia P, Zardi L and Righetti PG (2004) Blue silver: A very sensitive colloidal Coomassie G-250 staining for proteome analysis. Electrophoresis 25:13271333.

Carvalho MCCG, Caldas DGG, Carneiro RT, Moon DH, Salvatierra GR, Franeschini LM, Andrade A, Celedon PAF, Oda $\mathrm{S}$ and Labate CA (2008) SAGE transcript profiling of the juvenile cambial region of Eucalyptus grandis. Tree Physiol 28:905-919.

Celedon PAF, Andrade A, Meireles KGX, Carvalho MCCG, Caldas DGG, Moon DH, Carneiro RT, Franceschini LM, Oda S and Labate CA (2007) Proteomic analysis of the cambial region in juvenile Eucalyptus grandis at three ages. Proteomics 7:2258-2274.

Dalessandro G and Northcote DH (1977a) Possible control sites of polysaccharide synthesis during cell growth and wall expansion of pea seedlings (Pisum sativum L.). Planta 134:39-44.

Dalessandro G and Northcote DH (1977b) Changes in enzymatic activities of nucleoside diphosphate sugar interconversions during differentiation of cambium to xylem in sycamore and poplar. Biochem J 162:267-279.

Doyle JJT and Doyle JL (1987) Isolation of plant DNA from fresh tissue. Focus 12:13-15.

Gibeaut DM and Carpita NC (1994) Biosynthesis of plant cell wall polysacharides. FASEB J 8:904-915.

Gibeaut DM (2000) Nucleotide sugars and glycosyltransferases for synthesis of cell wall matrix polysaccharides. Plant Physiol Biochem 38:69-80.

Hempel J, Perozich J, Romovacek H, Hinich A, Kuo I and Feingold DS (1994) UDP-glucose dehydrogenase from bovine liver primary structure and relationship to other dehydrogenases. Protein Sci 3:1074-1080.

Hinterberg B, Klos C and Tenhaken R (2002) Recombinant UDP-glucose dehydrogenase from soybean. Plant Physiol Biochem 40:1011-1017.

Hurkman WJ and Tanaka CK (1986) Solubilization of plant membrane proteins for analysis by two-dimensional gel electrophoresis. Plant Physiol 81:802-806.

Johansson H, Sterky F, Amini B, Lundeberg J and Kleczkowski LA (2002) Molecular cloning and characterization of a cDNA encoding poplar UDP-glucose dehydrogenase, a key gene of hemicellulose/pectin formation. Biochem Biophys Acta 1576:53-58.

Kärkönen A, Murigneux A, Martinant JP, Pepey E, Tatout C, Dudley BJ and Fry SC (2005) UDP-glucose dehydrogenases of maize: A role in cell wall pentose biosynthesis. Biochem J 391:409-415.

Klinghammer M and Tenhaken R (2007) Genome-wide analysis of the UDP-glucose dehydrogenase gene family in Arabidopsis, a key enzyme for matrix polysaccharides in cell walls. J Exp Bot 58:3609-3621.

Kunihiro S, Kawanishi Y, Sano M, Naito K, Matsuura Y, Tateno Y, Gojobori T, Yamagata Y, Abe K and Machida M (2002) A polymerase chain reaction-based method for cloning novel members of a gene family using a combination of degenerate and inhibitory primers. Gene 289:177-184.

Loewus F, Chen MS and Loewus MW (1973) The myo-inositol oxidation pathway to cell wall polysaccharides. In: Lowes F (ed) Biogenesis of Plant Cell Wall Polysaccharides. Academic Press, New York, pp 1-27.

Oka T and Jigami Y (2006) Reconstruction of de novo pathway for synthesis of UDP-glucuronic acid and UDP-xylose from intrinsic UDP-glucose in Saccharomyces cerevisiae. FEBS J 273:2645-2657.

Reiter WD and Vanzin GF (2001) Molecular genetics of nucleotide sugar interconversion pathways in plants. Plant Mol Biol 47:95-113.

Roberts RM and Loewus F (1973) The conversion of D-glucose$6-{ }^{14} \mathrm{C}$ to cell wall polysaccharide material in Zea mays in presence of high endogenous levels of myoinositol. Plant Physiol 52:646-650.

Robertson D, Beech I and Bolwell GP (1995) Regulation of the enzymes of UDP-sugar metabolism during differentiation of French bean. Phytochemistry 39:21-28.

Sasaki K and Taylor IEP (1984) Specific labeling of cell wall polysaccharides with myo- $\left[2-{ }^{3} \mathrm{H}\right]$ inositol during germination and growth of Phaseolus vulgaris L. Plant Cell Physiol 25:989-997.

Salzman RA, Fujita T, Zhu-Salzman K, Hasegawa PM and Versan RA (1999) An improved RNA isolation method for plant 
tissues containing high levels of phenolic compounds or carbohydrates. Plant Mol Biol Rep 17:11-17.

Sambrook J, Fritsch EF and Maniatis T (1989) Molecular Cloning: A Laboratory Manual. 2nd edition. Cold Spring Harbor Laboratory Press, Cold Spring Harbor.

Segel IH (1976) Biochemical Calculations. 2nd edition. John Wiley \& Sons, New York, 441 pp.

Seifert GJ (2004) Nucleotide sugar interconvertions and cell wall biosynthesis: How to bring the inside to the outside. Curr Opin Plant Biol 7:277-284.

Seitz B, Klos C, Wurm M and Tenhaken R (2000) Matrix polysaccharide precursors in Arabidopsis cell walls are synthesized by alternative pathways with organ-specific expression patterns. Plant J 21:537-546.

Stewart DC and Copeland L (1998) Uridine-5'-diphosphate dehydrogenase from soybean nodules. Plant Physiol 116:349355.

Stewart DC and Copeland L (1999) Kinetic properties of UDPglucose dehydrogenase from soybean nodules. Plant Sci 147:119-125.

Southern EM (1975) Detection of specific sequences among DNA fragments separated by gel eletrophoresis. J Mol Biol 98:503-517.

Tenhaken R and Thulke O (1996) Cloning of an enzyme that synthesizes a key nucleotide-sugar precursor of hemicellulose biosynthesis from soybean: UDP-glucose dehydrogenase. Plant Physiol 112:1127-1134.

Thompson JD, Higgins DG and Gibson TJ (1994) Clustal W: Improving the sensitivity of progressive multiple sequence alignment through sequence weighting, position-specific gap penalities and weigh matrix choice. Nucleic Acids Res 22:4673-4680.

Zablackis E, Huang J, Muller B, Darvill AG and Albersheim P (1995) Characterization of the cell-wall polysaccharides of Arabidopsis thaliana leaves. Plant Physiol 107:1129-1138.

\section{Internet Resources}

Mascot search engine for rapid protein identification using mass spectrometry data. MASCOT MS/MS Ion Search, http://www.matrixscience.com/ (November 11, 2009).

Multiple sequence alignment program ClustalW2, http://www.ebi.ac.uk/Tools/clustalw2/index.html (November 11, 2009).

National Center for Biotechnology Information, http://www.ncbi.nlm.nih.gov/ (November 11, 2009).

Populus genome Project, http://genome.jgi-psf.org/Poptr1_1/Poptr1_1.home.html/ (November 11, 2009).

\section{Supplementary Material}

The following online material is available for this article:

Table S1 - Peptide sequencing data of the recombinant UGDH protein shown in Figure 2, obtained by LCMS/MS.

Table S2 - Peptide sequencing data of UGDH proteins shown in Figure 7, identified by LC-MS/MS.

Figure S1 - Phylogenetic tree generated for the eucalyptus UGDH protein sequence and eight other plant species.

Figure S2 - Restriction map of the cloned E. grandis $U G D H$ cDNA.

This material is available as part of the online article from http://www.scielo.br/gmb.

Associate Editor: Carlos F.M. Menck

License information: This is an open-access article distributed under the terms of the Creative Commons Attribution License, which permits unrestricted use, distribution, and reproduction in any medium, provided the original work is properly cited. 


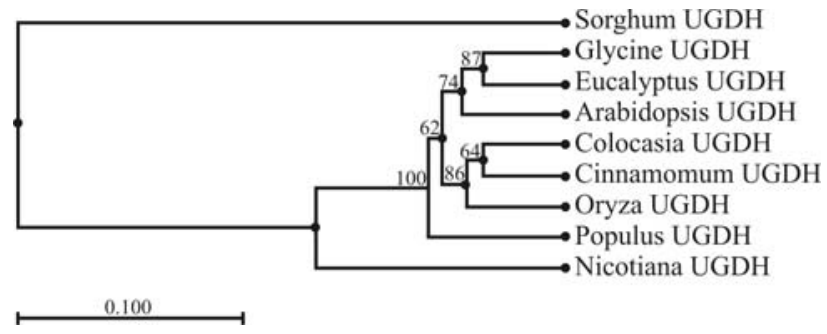

Figure S1 - Phylogenetic tree generated using CLC Main Work Bench 5.5 (UPGMA algorithm with Bootstrap analysis, 100 replicates) for the eucalyptus UGDH protein sequence and eight other plant species. The species and gi numbers are: Eucalyptus grandis, 144926039; Cinnamomum osmophloeum, 40317278; Populus tomentosa, 39939262; Glycine Max, 1518540; Arabidopsis thaliana, 11994517; Sorghum bicolor, 242047160; Nicotiana tabacum, 48093457; Colocasia esculenta, 29028306; Oryza sativa Japonica, Group 215737390.

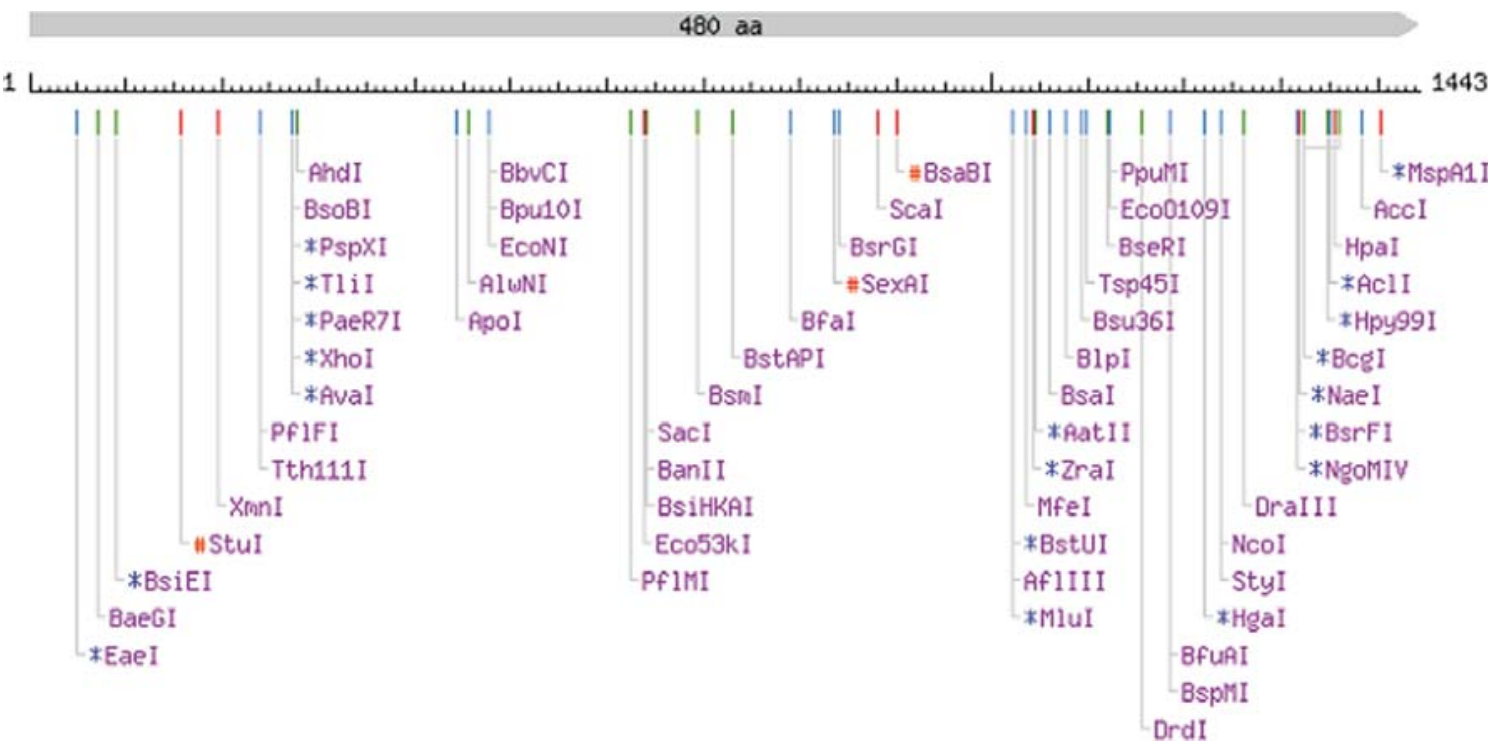

Figure S2 - Restriction map of the cloned E. grandis $U G D H$ cDNA. 
Table S1 - Peptide sequencing data of the recombinant UGDH protein of Figure 2, obtained by LC-MS/MS.

\begin{tabular}{|c|c|c|c|c|c|}
\hline $\begin{array}{l}\text { Name } \\
\text { EC 1.1.1.22 }\end{array}$ & $\%$ Probability & Peptide matches & Coverage (\%) & $\mathrm{Mr}^{1)}$ & $\mathrm{pI}^{2)}$ \\
\hline AAB58398 & 100 & 12 & 23.33 & 52.90816 & 5.93 \\
\hline Submitted mass & & \multicolumn{2}{|c|}{ Experimental mass } & Peptide sequences & \\
\hline 600.304 & & \multicolumn{2}{|c|}{1198.592} & (K)RAFFSTDVE & \\
\hline 951.99 & & \multicolumn{2}{|c|}{1901.964} & (K)HVFEADIVF & \\
\hline 677.302 & & \multicolumn{2}{|c|}{1352.588} & (K)AADLTYWES & \\
\hline 693.825 & & \multicolumn{2}{|c|}{1385.634} & (K)DVYAHWVP & \\
\hline 738.401 & & \multicolumn{2}{|c|}{1474.786} & (R)ILTTNLWSAI & \\
\hline 752.393 & & \multicolumn{2}{|c|}{1502.77} & (R)ILTTNLWSAI & \\
\hline 537.79 & & \multicolumn{2}{|c|}{1073.564} & (K)LAANAFLAC & \\
\hline 809.881 & & \multicolumn{2}{|c|}{1617.746} & (K)FLNASVGFG & \\
\hline 816.898 & & \multicolumn{2}{|c|}{1631.78} & (K)FLNASVGFG & \\
\hline 554.344 & & \multicolumn{2}{|c|}{1106.672} & (K)KIAILGFAFK & \\
\hline 731.863 & & \multicolumn{2}{|c|}{1461.71} & (K)KVSVVWDA & \\
\hline 740.368 & & \multicolumn{2}{|c|}{1478.72} & (K)KVSVVWDA & \\
\hline
\end{tabular}

${ }^{1)}$ Molecular weight in $\mathrm{kDa}$.

${ }^{2)}$ Isoelectric-point. 
Table S2 - Peptide sequencing data of UGDH proteins of Figure 7, identified by LC-MS/MS.

Spot 1

\begin{tabular}{|c|c|c|c|c|c|}
\hline $\begin{array}{l}\text { Name } \\
\text { EC 1.1.1.22 }\end{array}$ & Probability (\%) & Peptide matches & Coverage (\%) & Theoretical ${ }^{1)} \mathrm{Mr} / \mathrm{pI}^{2)}$ & Experimental ${ }^{1)} \mathrm{Mr} / \mathrm{pI}^{2)}$ \\
\hline$\underline{\mathrm{AAR} 32717}$ & 100 & 4 & 9 & $52.963 / 5.92$ & $57.907 / 6.39$ \\
\hline Submitted mass & & Charge & Experimental mass & \multicolumn{2}{|c|}{ Peptide sequences } \\
\hline 490.3026 & & 2 & 490.3026 & \multicolumn{2}{|c|}{ (K)IAILGFAFK(K) } \\
\hline 537.7942 & & 2 & 1073.5738 & \multicolumn{2}{|c|}{ (K)LAANAFLAQR(I) } \\
\hline 677.3171 & & 2 & 1352.6196 & \multicolumn{2}{|c|}{ (K)AADLTYWESAAR(T) } \\
\hline 738.3889 & & 2 & 1474.7632 & \multicolumn{2}{|c|}{ (R)ILTTNLWSAELSK(L) } \\
\hline
\end{tabular}

Spot 2

\begin{tabular}{|c|c|c|c|c|c|}
\hline $\begin{array}{l}\text { Name } \\
\text { EC 1.1.1.22 }\end{array}$ & Probability (\%) & Peptide matches & Coverage (\%) & Theoretical ${ }^{1)} \mathrm{Mr} / \mathrm{pI}^{2)}$ & Experimental ${ }^{1)} \mathrm{Mr} / \mathrm{pI}^{2)}$ \\
\hline$\underline{\mathrm{AAO} 62313}$ & 99.99 & 6 & 12 & $52.947 / 6.06$ & $57.625 / 6.44$ \\
\hline Submitted mass & & Charge & Experimental mass & \multicolumn{2}{|c|}{ Peptide sequences } \\
\hline 382.2243 & & 2 & 762.4340 & \multicolumn{2}{|c|}{ (R)MIADVSK(S) } \\
\hline 398.2232 & & 2 & 794.4318 & \multicolumn{2}{|c|}{ (K)TLDYQR(I) } \\
\hline 537.8185 & & 2 & 1073.6224 & \multicolumn{2}{|c|}{ (K)LAANAFLAQR(I) } \\
\hline 677.3301 & & 2 & 1352.6456 & \multicolumn{2}{|c|}{ (K)AADLTYWESAAR(M) } \\
\hline 462.9116 & & 3 & 1385.7130 & \multicolumn{2}{|c|}{ (K)DVYAHWVPEDR(I) } \\
\hline 738.4020 & & 2 & 1474.7894 & \multicolumn{2}{|c|}{ (R)IITTNLWSAELSK(L) } \\
\hline
\end{tabular}

Spot 3

\begin{tabular}{|c|c|c|c|c|c|}
\hline $\begin{array}{l}\text { Name } \\
\text { EC 1.1.1.22 }\end{array}$ & Probability (\%) & Peptide matches & Coverage (\%) & Theoretical ${ }^{1)} \mathrm{Mr} / \mathrm{pI}^{2}$ & Experimental ${ }^{1)} \mathrm{Mr} / \mathrm{pI}^{2)}$ \\
\hline$\underline{\mathrm{AAR} 32717}$ & 99.99 & 3 & 7 & $53.543 / 5.92$ & $59.101 / 6.61$ \\
\hline Submitted mass & & Charge & Experimental mass & \multicolumn{2}{|c|}{ Peptide sequences } \\
\hline 490.3130 & & 2 & 978.6114 & \multicolumn{2}{|c|}{ (K)IAILGFAFK(K) } \\
\hline 677.3294 & & 2 & 1352.6442 & \multicolumn{2}{|c|}{ (K)AADLTYWESAAR(T) } \\
\hline 738.4080 & & 2 & 1474.8014 & \multicolumn{2}{|c|}{ (R)ILTTNLWSAELSK(L) } \\
\hline
\end{tabular}

${ }^{1)}$ Molecular weight in kDa.

${ }^{2)}$ Isoelectric-point. 